\title{
A Review on Drivers and Barriers towards Sustainable Supply Chain Practices
}

\author{
Mee Yean Tay, Azmawani Abd Rahman, Yuhanis Abdul Aziz, and Shafie Sidek
}

\begin{abstract}
The rising environmental concerns are encouraging consumers to have greater awareness of their purchase decisions. Firms are implementing measures geared to offering green substitutes for traditional products and services. However, the effort towards sustainable supply chain management (SSCM) is not as straightforward since organization would face obstacles. The aim of this paper is to identify the barriers and drivers towards the implementation of the sustainable supply chain management (SSCM). Through the review of the literature, it was found that there are various factors that have been documented to influence an organization in making the decision towards SSCM implementation.
\end{abstract}

Index Terms-Green, sustainable, supply chain, drivers, barriers.

\section{INTRODUCTION}

Previous research suggests that the implementation of environmental initiatives for any company is an expensive cost which trickles down through all levels of the firm [1]. Consumers and companies alike are consequently have to be more willing to pay premium prices for green alternatives [2]. As with manufacturing firms, management is concerned that commitment to green initiatives will reduce profitability at the expense of actual environmental performance [3]. Besides that, managers' commitment to environmental investments in new greener markets will provide the firm with the innovation to gain a competitive advantage quickly [3]. Several multinational firms in diverse service industries have announced initiatives to going green in products sold, or in production processes. However, service firms consider the conflicts of diverse stakeholders, including customers, employees, suppliers, regulators, governmental agencies, and stockholders and their reactions to make green initiatives.

These groups establish conflicting priorities for management's policies - high return on investments, high quality products and prolonged profitability [4]. Thus, organizations face barriers and drivers to sustainable supply chain management [5], and these can be either internal or external challenges to the organization [6], [7]. The objective of this paper is to highlight the drivers and barriers towards sustainable supply chain practices by firms.

Manuscript received May 19, 2014; revised July 20, 2014.

M. Y. Tay, Y. Abdul Aziz, and S. Sidek are with the Faculty of Economics and Management, Universiti Putra Malaysia, Selangor, Malaysia (e-mail: meeyean8879@gmail.com, yuhanis@upm.edu.my, and shafiesidek@upm.edu.my).

A. Abd. Rahman is with the Halal Product Research Institute, Universiti Putra Malaysia, Serdang, Selangor, Malaysia (e-mail: azar@upm.edu.my).

\section{SUSTAINABLE DEVELOPMENT}

The term, sustainable development has evolved through the powerful lobbying of the environmental movement over the past 30 years. Bruntland's definition of sustainable development has become widely used. It defined sustainable development as invoking the needs of future generations counterbalanced to the current unmet needs of much of the world's population [8]. As a general concept, sustainable development encompasses three fundamental approaches: economic, environmental, and social developments, which are interrelated and complementary [8].

The focus of research in sustainability has shifted from local optimization in a single organization to that of the entire supply chain [9], [10]. Moreover, sustainability has become a lasting movement that has started to impact on how we do business, buy products and even choose our leaders. Environmental sustainability is a key issue for human societies throughout the $21^{\text {st }}$ century's world. It can be defined as meeting the needs of the present without compromising the ability of future generations to meet their needs [11]. As environment sustainability is attracting more attention, the literature on SSCM practices focusing on environmental performance has created a stream known as green supply chain management [12]. It is not simply about reducing the amount of waste of production or using less energy, but is concerned with developing processes that will lead to businesses becoming completely sustainable in the future.

The communities must not only be environmentally sustainable, they must be also socially sustainable. [13] state that social sustainability should be seen as: "A process for creating sustainable, successful places that promote wellbeing, by understanding what people need from the places they live and work. The literature has addressed the social dimension of sustainability by investigating various social aspects such as community issues, corporate governance, diversity considerations, employee relations, human rights and diversity, educational and ethical considerations, training and development and safety [14]-[16]. It is far more difficult to quantify than economic growth or environmental impact and consequently it is the most neglected element of triple bottom line reporting. Despite the business is large or small, they can actually contribute to social sustainability such as to improve local and global social conditions of workers, their families, communities and society at large.

Economic sustainability assesses various aspects of SCM focusing on ensuring healthy cash flow, good profit margins and a proper return on investment, business performance improvement and competitive advantage [17], [18]. Based on the literature on the economics of sustainability, it 
emphasizes utility, for which a value is computed [19], [20]. The costs of protecting the environment are frequently not onerous and in many instances, the cost savings from using resources more wisely and the reputational advantage in attracting customers from being known as a "green" organization increase organizational profitability [21], [22].

\section{Sustainable SupPly Chain MANAGEMENT}

The supply chain conceptually covers the entire physical process from obtaining the raw materials through all process steps until the finished product, directly or indirectly, reaches the end user as well as the associated information flows. In addition, most supply chains consist of many separate companies, each linked by virtue of their part in satisfying or fulfilling the specific need of the end consumer. In the supply chain, it is not only includes the manufacturer and suppliers, but also transporters, warehouses, retailers, and customers themselves. Supply chain management (SCM) concept had been initiated in 1980s.

The topic of sustainability in the context of SCM has been discussed using a number of terms in the literature. Sustainability has become a global concern and hence motivated organizations are revisiting their supply chain operations taking into consideration the environmental and social impacts of their supply chains [23]-[25]. In the recent years, this has given rise for the academic is embracing new term that most closely link sustainability and SCM concepts are green supply chain management (GSCM) and sustainable supply chain management (SSCM) [26]. From the study done by [27], the analysis results shows that integration of sustainability into SCM began by focusing on merging "green" considerations with SCM practices. Thus, SSCM is the extension concept of GSCM.

Ref. [28] defined SSCM as the strategic, transparent integration and achievement of an organization's social, environmental and economic goals in the systemic coordination of key inter-organizational business process for improving the long-term economic performance of the individual company and its supply chain. In addition, [5] refers to SSCM as the management of material, information and capital flows as well as cooperation among companies along the supply chain while taking goals from all three dimensions of sustainable development such as economic, environmental and social, into accounts which are derived from customer and stakeholder requirements.

People recognized that profits and profitability were the only element in the long-term success of businesses and the economic as the new economic order unfolded [29]. Also important are the stakeholders and the environment.

\section{A. Drivers towards SSCM}

SSCM incorporates with variety of concepts such as environmental or green supply chain, where firms seek to minimize negative environmental impacts in their supply chains. Firms differ in what causes them to engage in SSCM, with some firms being driven from within by their top management to engage in sustainable supply issues, and others responding reactively to external influences such as stakeholder pressures or customer requirements [30]. In this situation, organizations could face barriers and drivers to implementation of SSCM [5], and these can be either internal or external to the organization [31], [32]. For instances, the causes that for firms to engage in SSCM can be varied, with some firms being driven from within by their top management to participate themselves or not in sustainable supply issues, and others responding reactively to outside influences such as stakeholder pressures, customer requirements and the like.

Some of the internal drivers are on broad organizational issues including having top management commitment [33] and a supportive culture [34], [35]. The involvement of employees is also beneficial [36] including middle management [37]. SSCM is also benefited by adopting an Environmental Management System (EMS) [38]-[40]. Proactivity in SSCM may lead to firm competitiveness [41], [42] or help manage reputational and environmental risk [43]-[46]. Looking more specifically at the purchasing and supply function, developing capabilities is important [12], [47], [48], and specifying a sustainable SCM strategy is of benefit [6], [36], and ensuring it aligns with corporate strategy [49], [50]. Other internal corporate social responsibility (CSR) practices can influence SSCM [51].

TABLE I: DRIVERS TOWARDS SUSTAINABLE PRACTICES

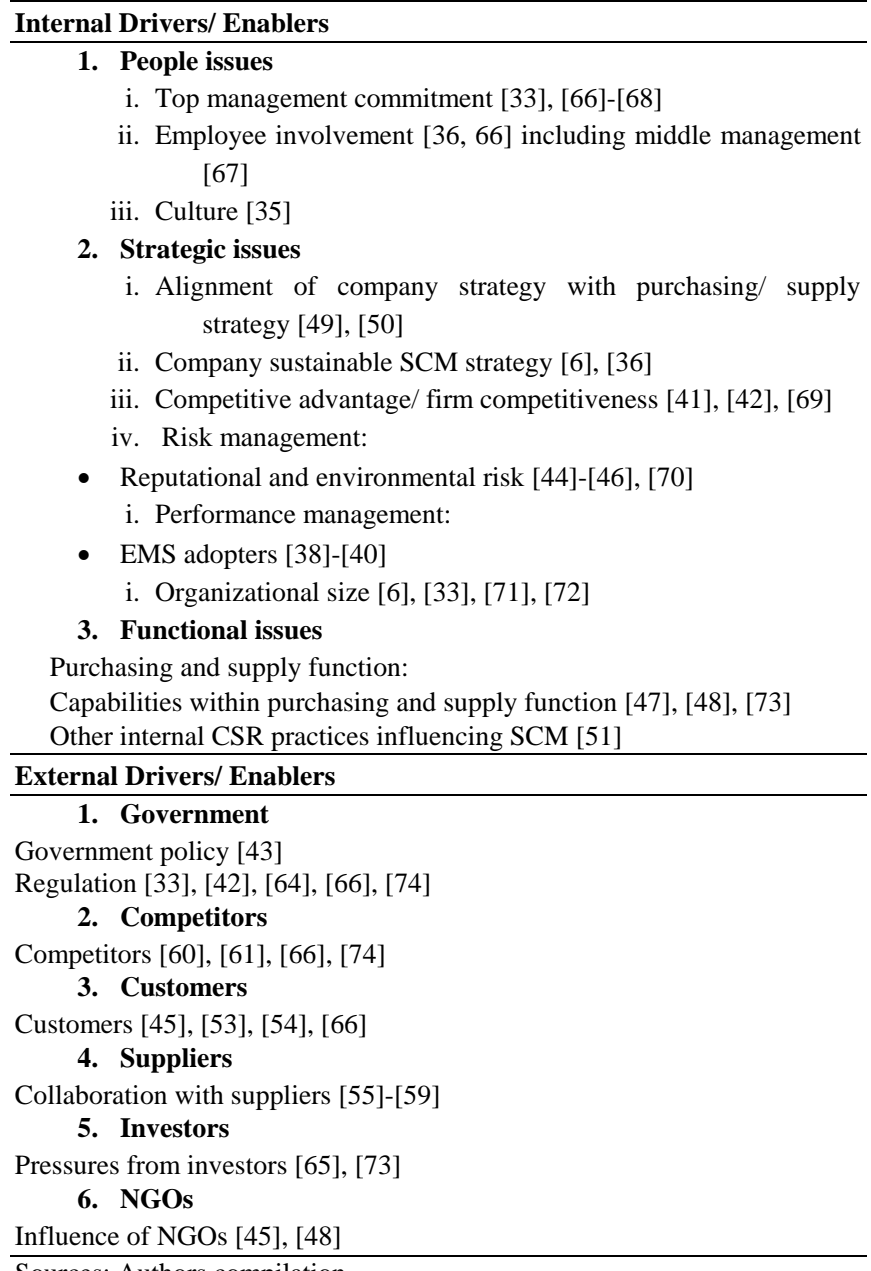

Sources: Authors compilation.

External drivers come from a range of stakeholders. Large customers may influence smaller suppliers to meet SSCM practices [45], [52], [53], and exert pressure in the supply chain [54]. Collaboration with suppliers is important for 
SSCM [55]-[59]. SSCM can enhance competitive advantage [60], [61]. Governments are influential through policy [62], [63] and regulation [33], [42], [52], [64]. NGOs exert pressure on firms [45], [48], as do investors [65].

Firms which behave proactively on environmental issues might be able to reap strategic advantage by foreseeing opportunities and problems throughout the entire chain. From the supply chain perspective, the market becomes a more plausible means of environmental improvement. From these observations, there are 3 main factors that relatively have high impact to an organization on the execution of SSCM which are (I) government, (II) employee and also (III) consumers. Table I summarizes the drivers for SSCM practices.

\section{B. Barriers of SSCM}

Moving to barriers to SSCM, a distinction can be drawn between large and small firms, with larger firms more likely to engage in SSCM [6], [33]. Generally, size is one of the most important firm characteristics expected to influence the adoption of green initiatives. According to [75], he also found that firm size is an influence factor for firm to practice on SSCM, bigger size firm tend to be more willing to participate in green supply chain initiative.

TABLE II: BARRIERS TOWARDS SUSTAINABLE PRACTICES

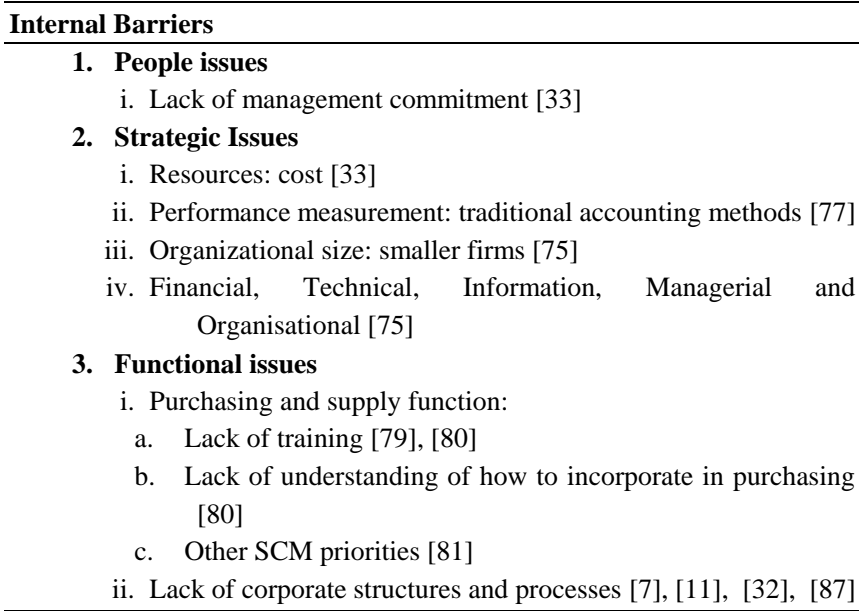

\section{External Barriers}

1. Government

i. Regulation [85]

2. Competitors

i. Competitive pressures [80]

3. Customers

i. Consumer desire for lower prices [82]

ii. Poor supplier commitment [7], [68]

4. Media

i. Green wash [84]

5. Sectoral

i. Less regulated industries $[33,86]$

6. Organization

i. Policy and Market Issues [87]

7. Technology

i. ICT [89]

Sources: Authors compilation.

Internal barriers include a lack of supportive corporate structures and processes [7], [10], [11], a lack of management commitment [33], [76], and a reliance on traditional accounting methods, which do not facilitate reporting on the triple bottom line [77]. Additional, lack of top management commitment is a major reason behind failure of quality improvement efforts [78] in the execution of SSCM, and unless management is fully committed to service excellence, any improvement efforts are doomed to failure from the start [78].

A focus on cost reduction can run counter to SSCM [33]. Looking at the purchasing and supply function, SSCM can be hindered by a lack of training [79], [80] and understanding [80] and having other SCM priorities [81]. Moreover, increased investment in green products, however, concerns many buying firms which believe that greater commitment to environmental programs increases total purchasing costs and subsequently decreases their competitiveness. As the consequences, a firm's strong environmental commitment results in added costs, which put the firm at an economic disadvantage as compared with other less environmentally responsible firms [33]. Another difficulty associated with formulating a green purchasing strategy is that green purchasing may reduce the pool of qualified suppliers due to stricter environmental quality standards [33].

External barriers include consumer desire for lower prices [82], competitive pressures [80], and "green washing" or PR exercise [83], [84]. Despite the growing attention, there have been criticisms and scepticisms of the adoption of environmental supply initiatives as being reactive to regulations [33], [83]. Government regulation can inhibit SSCM [86], as can a lack of commitment amongst suppliers [7], [67], and industry type [33], [86]. Table II summarizes the barriers of SSCM practices.

\section{CONCLUSION}

A SSCM strategy requires companies to adopt environmentally friendly purchasing, including taking into consideration the purchasing of materials that consist of less environmentally harmful elements, the use of fewer materials and more renewable and recyclable resources to deliver to the end user. Along the supply chain, suppliers, management and customers can influence the practices of an organization to make development more sustainable for the future. Collaboration with suppliers is important for SSCM [55]-[59].

Strategy research suggests that changes come not only from the top, but bleed through every aspect of the company, concluding that managers have a duty to the environment [1], [90]. Meanwhile, employees' commitment to environmental concerns may subsequently increase increasingly identify with the company's objectives [91], [92].

In conclusion, several initiatives can be undertaken to help firms adopt SSCM. Furthermore, focusing on supply chains is a step towards the broader adoption and development of sustainability, since the supply chain considers the product from initial processing of raw materials to delivery to the end customer [10]. As business move towards sustainability as key for competitive advantage and higher performance, they will need to develop even more collaborative and cross-functional supply chain teams. They will also benefit from exploring new business models with their suppliers, 
including opportunities for co-branding. As such, firms will need to continue to develop sophisticated new tools to measure and allocate the gains from sustainable practices among the supply chain's stakeholders. This will allow users to value the entire business ecosystems, which includes sustainability in assessing the total cost of an economic activity.

\section{REFERENCES}

[1] S. Hussain, "The ethics of going green: the corporate social responsibility debate," Business Strategy and the Environment, vol. 8 , no. 4, pp. 203-210, 1999.

[2] M. Laroche, J. Bergeron, and G. B. Forleo, "Targeting consumers who are willing to pay more for environmentally friendly products," Journal of Consumer Marketing, vol. 18, no. 6, pp. 503-520, 2001.

[3] N. Ahmed, "Environmental concerns, efforts and impact: an empirical study," Mid-American Journal of Business, vol. 18, no. 1, pp. 61-69, 2003.

[4] S. Feldman, "Does improving a firm's environmental management system and environmental performance result in a higher stock price?" Journal of Investing, vol. 6, no. 4, pp. 87-97, 1997.

[5] S. Seuring and M. Müller, "From a literature review to a conceptual framework for sustainable supply chain management," Journal of Cleaner Production, vol. 16, no. 15, pp. 1699-710, 2008.

[6] A. Hervani, M. Helms, and J. Sarkis, "Performance measurement for green supply chain management," Benchmarking: An International Journal, vol. 12, no. 4, pp. 330-353, 2005.

[7] H. Walker, L. D. Sisto, and D. McBain, "Drivers and barriers to environmental supply chain management practices: Lessons from the public and private sectors," Journal of Purchasing and Supply Management, vol. 14, no. 1, pp. 69-85, 2008.

[8] Brundtland Commission, Our Common Future, Oxford University Press: Oxford, 1987.

[9] J. Linton, R, Klassen, and V. Jayaraman, "Sustainable supply chains: An introduction," Journal of Operations Management, vol. 25, no. 6 , pp. 1075-1082, 2007

[10] S. Seuring, J. Sarkis, M. Müller, and P. Rao, "Sustainability and supply chain management-an introduction to the special issue," Journal of Cleaner Production, vol. 16, no. 15, pp. 1545-1551, 2008.

[11] United Nations, Global Compact Policy Dialogue: Latin American Workshop on Supply Chain Management, United Nations, Nova Lima, 2003.

[12] J. Sarkis, Q. Zhu, and K. Lai, "An organizational theoretic review of green supply chain management literature," International Journal of Production Economics, vol. 130, no. 1, pp. 1-15, 2011.

[13] J. Dillard, V. Dujon, and M. C. King, Understanding the Social Dimension of Sustainability, New York: Routledge, 2009, pp. 1-12.

[14] B. Chabowski, J. Mena, and T. G. Padron, "The structure of sustainability research in marketing,1958-2008: A basis for future research opportunities," Journal of the Academy of Marketing Science, vol. 39, no. 1, pp. 55-70, 2011.

[15] D. Closs, C. Speier, and N. Meacham, "Sustainability to support end-to-end value chains: The role of supply chain management," Journal of the Academy of Marketing Science, vol. 39, no. 1, pp 101-116, 2011

[16] A. Scott, "Corporate social responsibility greening the supply chain," Chemical Week, vol. 173, no. 8, pp. 21-24, 2011.

[17] K. McCormack, M. B. Ladeira, and M. P. V. de Oliveira, "Supply chain maturity and performance in brazil," Supply Chain Management: An International Journal, vol. 13, no. 4, pp. 272-282, 2008.

[18] D. J. Ketchen, G. Tomas, and M. Hult, "Building theory about supply chain management: Some tools from the organizational sciences," Journal of Supply Chain Management, vol. 47, no. 2, pp. 12-18, 2011.

[19] R. Goodland and H. Daly, "Environmental Sustainability: Universal and Negotiable," Ecological Applications, vol. 6, no. 4, pp. 1002-1017, 1996.

[20] J. Pezzey, "Sustainability: an interdisciplinary guide," Environmental Values, vol. 1, no. 4, pp. 321-362, 1992.

[21] A. Bernstein, "Incorporating labor and human rights risk into investment decisions," Occasional Paper Series No. 2. Pensions and Capital Stewardship Project, Labor and Worklife Program, no. 2, 2008.

[22] J. Pfeffer, "Building sustainable organizations: the human factor," The Academy of Management Perspectives, vol. 24, no. 1, pp. 34-45, 2010.
[23] N. Capaldi, "Corporate social responsibility and the bottom line," International Journal of Social Economics, vol. 32, no. 5, pp. 408-423, 2005.

[24] C. R. Carter and P. L. Easton, "Sustainable supply chain management: Evolution and future directions," International Journal of Physical Distribution \& Logistics Management, vol. 41, no. 1, pp. 46-62, 2011.

[25] A. Chaabane, A. Ramudhin, and M. Paquet, "Design of sustainable supply chains under the emission trading scheme," International Journal of Production Economics, vol. 135, no. 1, pp. 37-49, 2012.

[26] A. Ashby, M. Leat, and M. H. Smith, "Making connections: a review of supply chain management and sustainability literature," Supply Chain Management: An International Journal, vol. 17, no. 5, pp. 497-516, 2012.

[27] P. Ahi and C. Searcy, "A comparative literature analysis of definitions for green and sustainable supply chain management," Journal of Cleaner Production, vol. 52, pp. 329-341, 2013.

[28] C. Carter and D. Rogers, "A framework of sustainable supply chain management: moving toward new theory," International Journal of Physical Distribution and Logistics Management, vol. 38, no. 5, pp. 360-387, 2008.

[29] B. L. Hay, R. N. Stavins, and R. H. K. Vietor, "The Four questions of corporate social responsibility: may they, can they, do they, should they?" Environmen, in R. S. Stavins, R. V. Stavins, and B. Hay, Ed., Washington, DC, Resources for the Future, 2005.

[30] H. Walker and N. Jones, "Sustainable supply chain management across the UK private sector," Supply Chain Management: an International Journal, vol. 17, no. 1, pp. 15-28, 2012.

[31] A. Hervani, M. M. Helms, and J. Sarkis, "Performance measurement for green supply chain management," Benchmarking: an International Journal, vol. 12, no. 4, pp. 330-353, 2005.

[32] H. Walker and L. Preuss, "Fostering sustainability through sourcing from small businesses: public sector perspectives," Journal of Cleaner Production, vol. 16, no. 15, pp. 1600-1609, 2008.

[33] H. Min and W. P. Galle, "Green purchasing practices of US firms," International Journal of Operations \& Production Management, vol. 21, no. 9, pp. 1222-1238, 2001

[34] C. R. Carter and M. Jennings, "The role of purchasing in corporate social responsibility: a structural equation analysis," Journal of Business Logistics, vol. 25, no. 1, pp. 145-186, 2004.

[35] A. Hughes, "Corporate strategy and the management of ethical trade: the case of the UK food and clothing retailers," Environment and Planning A, vol. 37, no. 7, pp. 1145-1163, 2005.

[36] M. D. Hanna, W. R. Newman, and P. Johnson, "Linking operational and environmental improvement through employee involvement," International Journal of Operations and Production Management, vol. 20, no. 2, pp. 148-165, 2000.

[37] S. New, K. Green, and B. Morton, "Buying the environment: the multiple meanings of green supply," in the Business of Greening, S Fineman Ed., Routledge, London, pp. 33-53, 2000.

[38] C. C. Chen, "Incorporating green purchasing into the frame of ISO 14000," Journal of Cleaner Production, vol. 13, no. 9, pp. 927-33, 2005.

[39] N. Darnall, G. Jolley, and R. Handfield, "Environmental management systems and green supply chain management: complements for sustainability?" Business Strategy and the Environment, vol. 18, no. 1, pp. 30-45, 2008.

[40] R. Handfield, R. Sroufe, and S. Walton, "Integrating environmental management and supply chain strategies," Business Strategy and the Environment, vol. 14, no. 1, pp. 1-19, 2005.

[41] S. Sharma and H. Vredenburg, "Proactive corporate environmental strategy and the development of competitively valuable organisational capabilities," Strategic Management Journal, vol. 19, no. 8, pp. 729-253, 1998.

[42] Q. H. Zhu, J. Sarkis, and Y. Geng, "Green supply chain management in China: pressures, practices and performance," International Journal of Operations \& Production Management, vol. 25, no. 5-6, pp. 449-468, 2005.

[43] C. R. Carter and J. R. Carter, "Inter-organizational determinants of environmental purchasing: initial evidence from the consumer products industries," Decision Sciences, vol. 29, no. 3, pp. 659-684, 1998.

[44] P. Cousins, R. Lamming, and F. Bowen, "The role of risk in environment-related supplier initiatives," International Journal of Operations and Production Management, vol. 24, no. 6, pp. 554-565, 2004.

[45] J. Hall, "Environmental supply chain innovation," Greener Management International, no. 35, pp. 105-119, 2001.

[46] P. Teuscher, B. Gruninger, and N. Ferdinand, "Risk management in sustainable supply chain management: lessons learnt from the case of 
GMO-free soybeans," Corporate Social Responsibility and Environmental Management, vol. 13, no. 1, pp. 1-10, 2006.

[47] P. D. Jennings and P. A. Zandbergen, "Ecologically sustainable organisations: an institutional approach," Academy of Management Review, vol. 20, no. 4, pp. 1015-1052, 1995.

[48] I. Maignan, B. Hillebrand, and D. McAlister, "Managing socially-responsible buying: how to integrate noneconomic criteria into the purchasing process," European Management Journal, vol. 20, no. 6 , pp. 641-648, 2002.

[49] M. Day and S. Lichtenstein, "Strategic supply management: the relationship between supply management practices, strategic orientation and their impact on organisational performance," Journal of Purchasing and Supply Management, vol. 12, no. 6, pp. 313-312, 2006.

[50] R. Narasimhan and A. Das, "The impact of purchasing integration practices on manufacturing performance," Journal of Operation. Management, vol. 19, no. 5, pp. 593-609, 2001.

[51] J. Meehan, K. Meehan, and A. Richards, "Corporate social responsibility: the 3C-SR model," International Journal of Social Economics, vol. 33, no. 5-6, pp. 386-398, 2006.

[52] J. Hall, "Environmental supply chain dynamics," Journal of Cleaner Production, vol. 8, no. 6, pp. 455-471, 2000.

[53] S. Walton, R. Handfield, and S. Melnyk, "The green supply chain integrating suppliers into environmentalmanagement processes,' International Journal of Purchasing and Materials Management, vol. 3, no. 2, pp. 2-11, 1998.

[54] R. Handfield, S. V. Walton, L. K. Seegers, and S. A. Melnyk, "Green value chain practices in the furniture industry," Journal of Operations Management, vol. 15, no. 4, pp. 293-315, 1997.

[55] S. Seuring and M. Müller, "Core issues in sustainable supply chain management - a Delphi study," Business Strategy and the Environment, vol. 17 , no. 8, pp. 455-466, 2007.

[56] M. Sharfman, T. Shaft, and R. Anex, "The road to cooperative supply-chain environmental management: trust and uncertainty among pro-active firms and the Environment," Business Strategy, vol. 18, no. 1, pp. 1-13, 2007

[57] S. Vachon and R. D. Klassen, "Environmental management and manufacturing performance: the role of collaboration in the supply chain," International Journal of Production Economics, vol. 111, no. 2 , pp. 299-315, 2008.

[58] S. Vachon and R. D. Klassen, "Supply chain management and environmental technologies: the role of integration," International Journal of Production Research, vol. 45, no. 2, pp. 401-423, 2007.

[59] K. Verghese and H. Lewis, "Environmental innovation in industrial packaging: a supply chain approach," International Journal of Production Research, vol. 45, no. 18-19, pp. 4381, 2007.

[60] M. Forman and J. Sogaard, "Organising environmental supply chain management: experience from a sector with frequent product shifts and complex product chains: the case of the Danish textile sector," Greener Management International, no. 45, pp. 43-62, 2004

[61] L. Preuss, "Buying into our future: the range of sustainability initiatives in local government procurement," Business Strategy and the Environment, vol. 16, no. 5, pp. 354-365, 2007.

[62] C. R. Carter and L. M. Ellram, "Reverse logistics: a review of the literature and framework for future investigation," International Journal of Purchasing and Materials Management, vol. 34, no. 4, pp. 28-38, 1998.

[63] J. D. Linton, R. Klassen, and V. Jayaraman, "Sustainable supply chains an introduction," Journal of Operations Management, vol. 25, no. 6, pp. 1075-1082, 2007.

[64] L. Preuss, "Rhetoric and reality of corporate greening: a view from the supply chain management function," Business Strategy and the Environment, vol. 14, no. 2, pp. 123-139, 2005.

[65] P. Trowbridge, "A case study of green supply-chain management at advanced micro devices," Greener Management International, vol. 35, pp. 121-135, 2001.

[66] P. Evangelista, E. Sweeney, G. Ferruzzi, and J. C. Carrasco, "Green supply chain initiatives in transport and logistics service industry: an exploratory case study analysis," in Proc. the Logistics Research Network Conference Towards the Sustainable Supply Chain: Balancing the needs of Business, Economy and the Environment, Harrogate, UK,Sept 8-10, 2010, pp. 195-203.

[67] I. Wycherley, "Greening supply chains: the case of the Body Shop International," Business Strategy and the Environment, vol. 8, no. 2, pp. 120-127, 1999.

[68] S. New, K. Green, and B. Morton, "Buying the environment: the multiple meanings of green supply", in the Business of Greening, $\mathrm{S}$. Fineman, Ed., Routledge, London, 2000, pp. 33-53.
[69] A. Ashish, and A. Nandkumar, "Insecure advantage? Markets for technology and the value of resources for entrepreneurial ventures," Strategic Management Journal, vol. 33, no. 3, pp. 231-251, 2012.

[70] P. Schwartz, "When good companies do bad things," Strategy and Leadership, vol. 28, no. 3, pp. 4-12, 2000.

[71] C. Y. Lin and Y. H. Ho, "An empirical study on logistics service providers' intention to adopt green innovations," Journal of Technology Management \& Innovation, vol. 3, no. 1, pp. 17-26, 2008.

[72] Y. H. Ho, C. Y. Lin, and S. H. Chiang, "Organizational determinants of green innovation implementation in the logistics industry," The International Journal of Organizational Innovation, vol. 2, no. 1, pp. 5-12, 2009.

[73] K. Green, B. Morton, and S. New, "Purchasing and environmental management: interactions, policies and opportunities," Supply Chain Management, vol. 3, no. 2, pp. 89-95, 1996.

[74] K. Isaksson and M. H. Brodin, "Driving forces and barriers when pricing the environmental service offering, a cross case study of logistics companies, towards the sustainable supply chain: balancing the needs of business, economy and the environment," in Proc. the 15th Annual LRN Conference, in T. Whiteing, Ed., Harrogate, UK, 2010, pp. 303-311

[75] S. Y. Lee, "Drivers for the participation of small and medium-sized suppliers in green supply chain initiatives," Supply Chain Management: An International Journal, vol. 13, no. 3, pp. 185-198, 2008.

[76] C. R. Carter and M. Dresner, "Purchasing's role in environmental management: cross-functional development of grounded theory," Supply Chain Management, vol. 37, no. 3, pp. 12-26, 2001

[77] P. Rao and D. Holt, "Do green supply chains lead to competitiveness and economic performance?" International Journal of Operations and Production Management, vol. 25, no. 9, pp. 898-916, 2005.

[78] E. Babakus, The Effect of Management Commitment to Service Quality on Employees 'Affective and Performance Outcomes, 2003.

[79] F. E. Bowen, P. D. Cousins, R. C. Lamming, and A. C. Farukt, "The role of supply management capabilities in green supply," Production and Operations Management, vol. 10, no. 2, pp. 174-189, 2001

[80] R. W. Cooper, G. L. Frank, and R. A. Kemp, "A multinational comparison of key ethical issues, helps and challenges in the purchasing and supply management profession: the key implications for business and the professions," Journal of Business Ethics, pp $83-100,2000$.

[81] V. Tummala, C. Phillips, and M. Johnson, "Assessing supply chain management success factors: a case study," Supply Chain Management: An International Journal, vol. 11, no. 2, pp. 179-192, 2006

[82] R. J. Orsato, "When does it pay to be green," California Management Review, vol. 48, no. 2, pp. 127-144, 2006

[83] A. Adedamola and E. C. Kingsley, "Staff perception of sustainable procurement - a study of the university of brighton," Journal of Educational and Management Studies, vol. 3, no. 1, pp. 115-122, 2013

[84] J. Greer and K. Bruno, Green Wash: The Reality Behind Corporate Environmentalism, New York: Apex Press. New York: Apex Press, 1996.

[85] M. E. Porter and C. V. der Linde, "Green and competitive: ending the stalemate green and competitive," Harvard Business Review, vol. 73, no. 5 , pp. 120-134, 1995

[86] Q. Zhu and J. Sarkis, "An inter-sectoral comparison of green supply chain management in China: drivers and practices," Journal of Cleaner Production, vol. 14, no. 5, pp. 472-486, 2006.

[87] A. Griffiths and J. A. Petrick, "Corporate architectures for sustainability," International Journal of Operations and Production Management, vol. 21, no. 12, pp. 1573-1585, 2001

[88] ETTAR project, "Transport and the environment: barriers to the take up of environmental technologies in the transport sector," Summary Report, Gothenburg, Sweden, 2007, Oct 25-26.

[89] S. Zailani, A. Amran, and H. Jumadi, "Green innovation adoption among logistics service providers in Malaysia: an exploratory study on the managers' perceptions," International Business Management, vol. 5, no. 3, pp. 104-113, 2011.

[90] S. R. Hume and L. Gallagher, "The value for service industry firms of environmental initiatives," Management Research Review, vol. 33, no. 11 , pp. $1054-1063,2010$

[91] C. A. Enz and J. A. Siguaw, "Best hotel environmental practices," Cornell Hotel and Restaurant Administration Quarterly, vol. 40, no. 5 , pp. 72-77, 1999.

[92] G. I. Kassinis and A. C. Soteriou, "Greening the service profit chain: the impact of environmental management practices," Production and Operations Management, vol. 12, no. 3, 2003. 


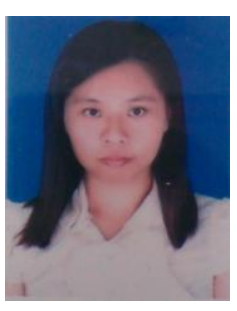

Mee Yean Tay was born in year 1988 in Batu Pahat, Johor, Malaysia. She received her bachelor degree major in German language and minor in management from Universiti Putra Malaysia (UPM) in year 2010. She obtained her master of business administration (MBA) from in UPM in year 2013 with a major in human resource management. Upon her completion in MBA, she continues her Ph.D. in business economics in UPM. Her current research interests include sustainable supply chain management and the implication on performance.

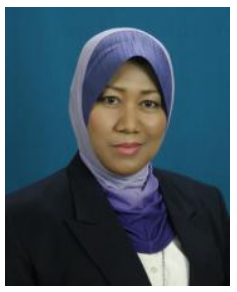

Azmawani Abd Rahman is an associate professor and deputy dean for research and graduate studies at Faculty of Economics and Management, Universiti Putra Malaysia (UPM). She holds a bachelor of science in finance from the University of South Alabama, United States and $\mathrm{PhD}$ in operations and technology management from the Aston University, United Kingdom. Currently she is an associate researcher at Halal Product Research Institute, UPM. She has published research papers in refereed journals which include Transaction on Engineering Management (IEEE), Journal of Manufacturing Technology Management, and International Journal of Production Research. Her research interests are in the areas of advanced manufacturing technology management, manufacturing supply chain management, Halal product and tourism supply chain management, and organizational culture.

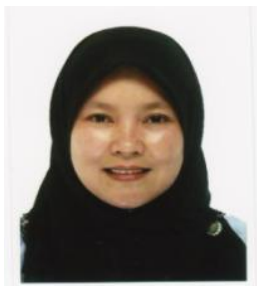

Yuhanis Abdul Aziz is an associate professor at the Department of Management and Marketing, Faculty of Economic and Management at University Putra Malaysia. She received her PhD degree in business and management from the University of Nottingham, UK. Her research interests cover a range of area in services marketing which includes service quality and customer satisfaction, customer experience management, branding and tourism and hospitality marketing. Additionally, she has carried out research in the areas of corporate communication and corporate reputation. Dr. Yuhanis research work has appeared in marketing and management as well tourism Journal such as Marketing Intelligence and Planning, Social Responsibility Journal, Journal of International Food and Agribusiness Marketing, International Journal of Economics and Management, and Journal of Educational Travel. Dr. Yuhanis currently serves as one of the associate Journal editor for Asian Journal of Case Research (AJCR) and IJEM (International Journal of Economics and Management.

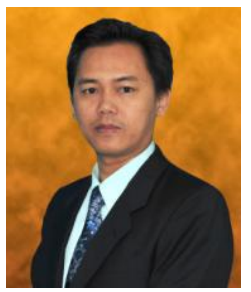

Shafie Sidek is a senior lecturer in Faculty of Economic and Management, Universiti Putra Malaysia. He holds bachelor of engineering in electrical, electronics and system and master of business administration from Universiti Kebangsaan Malaysia, and doctor of business administration from The University of Newcastle, Australia where his research specializes in entrepreneurship, innovation and technology management. $\mathrm{He}$ is currently a co-researcher at Advance Technology Institute (ITMA) for enhancing productivity and sustainability of Palm Oil Milling Industry in Malaysia focusing on the economic, social and environmental impact of palm oil milling technology. 